\title{
Pengaruh Formula Bebas Laktosa Terhadap Lama Diare dan Elektrolit Serum pada Anak dengan Diare Rotavirus
}

\author{
I Putu Gede Karyana, Nyoman Budihartawan, I GN Sanjaya Putra \\ Bagian/SMF Ilmu Kesehatan Anak Fakultas Kedokteran Universitas Udayana/RSUP Sanglah, Denpasar
}

\begin{abstract}
Latar belakang. Diare akut rotavirus menyebabkan kerusakan mukosa, vili usus menjadi tumpul dan pendek, serta kematian sel. Proses tersebut juga mengurangi sekresi enzim laktosa yang bertanggung jawab dalam penyerapan laktosa. Laktosa yang tidak terserap menyebabkan berkembangnya diare osmotik yang mengakibatkan kehilangan cairan dan elektrolit. Formula bebas laktosa dapat diserap tanpa membutuhkan enzim laktose, sehingga lama dari episode diare dapat dipersingkat.

Tujuan. Untuk membandingkan lama diare dan elektrolit serum pada bayi dan anak dengan diare rotavirus setelah pemberian nutrisi formula bebas laktosa dibandingkan dengan formula standar.

Metode. Uji klinis acak terkontrol tersamar ganda desain pararel, pada anak usia $\geq 6-\leq 59$ bulan dengan diare akut, dibagi 2 kelompok dengan besar sampel masing-masing 30 (kelompok A formula bebas laktosa; B formula standar). Latex agglutination test digunakan untuk mendeteksi rotavirus. Setelah dilakukan rehidrasi, diberikan intervensi. Observasi dilakukan tiap 6 jam untuk mengetahui durasi diare, berat badan, dan frekuensi defekasi. Analisis statistik dengan paired dan independent t-test dan analisis multivariat (cox regression).

Hasil. Rerata lama diare pada kelompok bebas laktosa 57,59 jam (SB 9,40) dan formula standar 85,97 (SB 13,94) jam, dengan beda rerata 28,38 (SE 3,09) jam (IK95\% 22,19;34,56; p=0,001). Penurunan frekuensi defekasi bermakna pada kelompok bebas laktosa, tetapi tidak bermakna pada peningkatan berat badan. Analisis multivariat menunjukkan hanya intervensi yang diberikan berpengaruh secara bermakna terhadap lama diare diare. Rerata peningkatan serum elektrolit hanya bermakna pada serum natrium, yaitu pada kelompok formula bebas laktosa dengan rerata 1,62 (SB4,20) $\mathrm{mEq} / \mathrm{L}(\mathrm{IK} 95 \%-2,83 ; 0,41 ; \mathrm{p}=0,01)$.

Kesimpulan. Formula bebas laktosa dapat mempersingkat lama diare dan meningkatkan kadar serum natrium pada diare rotavirus. Sari Pediatri 2012;14(2):137-42.
\end{abstract}

Kata kunci: diare akut rotavirus, formula bebas laktosa, serum elektrolit

\footnotetext{
Alamat korespondensi:

Dr. I Putu Gede Karyana, Sp.A. Divisi Gastrohepatologi Bag./SMF Ilmu Kesehatan Anak FK UNUD/RSUP Sanglah Denpasar Jl. Pulau Nias Denpasar Bali. Telp./Fax.: (0361) 244038. E-mail: kyn_karyana@ yahoo.co.id
}

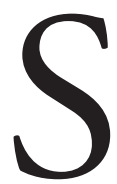

ampai saat ini diare atau gastroenteritis, masih merupakan salah satu penyebab utama kematian dan kesakitan pada anak di dunia, dan diperkirakan menyebabkan 1,87 juta kematian pada anak kurang dari 5 tahun, atau setara 
$19 \%$ dari semua kematian anak setiap tahun. ${ }^{1}$

Sistem surveilen terpadu (SST) tahun 2000 melaporkan angka kesakitan diare akut pada balita 21,45 per 1.000 penduduk dengan case fatality rate 5,27 per 1.000 kasus. Hasil Surkesnas tahun 2001 melaporkan diare tetap menjadi penyebab kematian bayi nomor 3 serta kematian balita nomor 2 yaitu 2,3 per 1.000 balita. $^{2}$

Penyebab utama diare akut pada anak adalah infeksi virus, terutama rotavirus. Virus ini terutama menyerang anak berumur 6-24 bulan. ${ }^{3}$ Asian Rotavirus Surveillance Network (ARSN) melaporkan 45\% anak dibawah 5 tahun di Asia Selatan dirawat di rumah sakit karena diare rotavirus. ${ }^{4}$ Lima persen dari kematian anak dibawah 5 tahun di negara berkembang disebabkan rotavirus. ${ }^{4,5}$

Dehidrasi dan gangguan elektrolit pada diare menyebabkan keadaan yang sangat berbahaya dan mengancam hidup. Upaya rehidrasi oral (URO) merupakan langkah penting dalam tata laksana diare akut, walaupun URO tidak dapat mempersingkat lama diare. ${ }^{6}$

Pemberian nutrisi (termasuk susu) yang tepat dapat membantu mempersingkat lama diare dan mencegah diare berulang. ${ }^{7}$ Pada metaanalisis penggunaan non human milk disimpulkan bahwa sebagian besar kasus diare akut dapat ditata laksana dengan formula tanpa diencerkan dan penggunaan formula bebas laktosa tidak perlu. ${ }^{8}$ Tetapi munculnya intoleransi laktosa tak sepenuhnya dapat diabaikan. Infeksi rotavirus menyebabkan kerusakan mukosa, penumpulan dan pemendekan vili serta kematian sel sehingga sekresi enzim disakaridase (terutama laktase) berkurang, sehingga terjadi intoleransi laktosa. ${ }^{9,10}$ Laktosa yang tidak terserap karena penurunan enzim laktase merupakan bahan osmotik aktif yang menyebabkan diare osmotik, sehingga menyebabkan kehilangan cairan dan elektrolit seperti, Natrium, Kalium, dan Klorida. ${ }^{11}$ Pada keadaan tersebut pemberian formula bebas laktosa dapat mengurangi laktosa dalam lumen usus, sehingga memperpendek lama diare dan mengurangi frekuensi buang air besar sehingga dapat menyebabkan penyerapan zat gizi lebih baik dan regenerasi sel-sel vili usus lebih cepat. ${ }^{10}$

Tujuan penelitian kami menguji formula yang tepat untuk tata laksana nutrisi bagi bayi dan anak dengan diare rotavirus. Tujuan khusus untuk membandingkan lama diare dan kadar serum elektrolit pada bayi dan anak dengan diare rotavirus setelah tata laksana nutrisi formula bebas laktosa dibandingkan dengan formula standar.

\section{Metode}

Penelitian uji klinis acak terkontrol tersamar ganda dengan desain pararel, dibagi menjadi 2 kelompok yang disusun secara paralel yaitu kelompok A (formula bebas laktosa ) dan B (formula standar/mengandung laktosa). Subyek adalah bayi dan anak dengan diare rotavirus yang dirawat di Divisi Gastrohepatologi Bagian/SMF Ilmu Kesehatan Anak Rumah Sakit Umum Pusat Sanglah, Denpasar antara 16 Juni 2008 sampai dengan 25 Oktober 2008. Kriteria inklusi adalah pasien diare akut rotavirus dehidrasi ringan sedang sesuai dengan kriteria MTBS yang telah terehidrasi, berumur $\geq 6$ bulan $-\leq 59$ bulan, lama diare saat masuk rumah sakit $\leq 48$ jam, orangtua pasien bersedia ikut dalam penelitian dan menandatangani informed consent. Kriteria eksklusi adalah pasien diare akut disertai komplikasi, diare bermasalah, mendapat terapi antibiotik ataupun mendapat antispasmodik dan atau antisekretorik, gizi buruk, mendapat air susu ibu (ASI) serta menderita intoleransi laktosa.

Subyek penelitian diambil secara consecutive sampling. Besar subyek menggunakan perkiraan untuk uji hipotesis terhadap rerata 2 populasi, ${ }^{12}$ dengan memperhitungkan $=0,05 ;=0,2$; rerata lama diare dengan formula bebas laktosa $=77$ jam; rerata lama diare dengan formula bayi $=100,2$ jam. ${ }^{10}$ Didapat jumlah sampel minimal masing-masing kelompok adalah 27 dengan perkiraan drop out $10 \%$, maka besar sampel tiap kelompok adalah 30. Jumlah total subyek adalah 60 .

Bayi dan anak dengan diare dianamnesis dan dilakukan pemeriksaan fisik untuk menentukan derajat dehidrasi. Pengambilan sampel darah untuk pemeriksaan elektrolit (Natrium, Kalium, dan Klorida) yang pertama dilakukan sebelum URO dilaksanakan. Pemeriksaan serum elektrolit yang kedua dilakukan 48 jam kemudian. Apabila URO gagal dilanjutkan dengan pemberian cairan parenteral. Setelah terehidrasi, dilakukan pengukuran lingkar lengan atas ( LLA) serta penimbangan berat badan.

Subyek diberikan formula oleh residen yang bertugas saat itu sesuai dengan nomor urut pasien (formula dikemas dengan kemasan yang sama dan diberikan nomor 1 sampai dengan 60). Cairan 
parenteral dihentikan, cairan pemeliharaan dipenuhi dengan pemberian formula yang diuji. Volume cairan yang diberikan mengikuti perhitungan cairan dengan metode Holiday-Segar. Subyek diberikan makanan setelah terehidrasi sesuai dengan makanan yang disediakan oleh rumah sakit (tidak mengandung laktosa).

Observasi dilakukan tiap 6 jam oleh residen yang bertugas. Peningkatan berat badan diukur sekali lagi setelah dinyatakan sembuh. Setelah dinyatakan sembuh, segel dibuka, jenis formula dapat dilihat dan orangtua diberikan petunjuk tentang penggantian kembali ke susu formula sebelumnya jika mendapat formula bebas laktosa.

\section{Hasil}

Selama periode penelitian 121 bayi dan anak yang berumur $\geq 6$ bulan $\leq 59$ bulan menderita diare akut dan 62 di antaranya menderita diare rotavirus. Enam puluh pasien diare rotavirus menjadi subyek penelitian. Dua menolak menandatangani informed consent (Gambar 1).

Tabel 1. Karakteristik dasar subyek

\begin{tabular}{|c|c|c|}
\hline Karakteristik & $\begin{array}{l}\text { Formula bebas } \\
\text { laktosa }(\mathrm{n}=29)\end{array}$ & $\begin{array}{l}\text { Formula mengandung laktosa } \\
\qquad(\mathrm{n}=31)\end{array}$ \\
\hline Usia (bulan), rerata $(\mathrm{SB})$ & $16,97(12.01)$ & $19.23(10,10)$ \\
\hline Laki-laki, n (\%) & $14(23,3)$ & $14(23,3)$ \\
\hline Berat badan saat masuk rumah sakit, $(\mathrm{kg})(\mathrm{SB})$ & $9,4(2,2)$ & $9.8(2,4)$ \\
\hline Frekuensi diare sebelum masuk rumah sakit, rerata (SB) & $10,10(1,76)$ & $9,74(1,84)$ \\
\hline Lama diare sebelum masuk rumah sakit (jam), rerata(SB) & $30,97(9,64)$ & $29,71(11,27)$ \\
\hline Volume formula yang dikonsumsi (ml), rerata, $(\mathrm{SB})$ & $200,72(26,70)$ & $209,97(30,70)$ \\
\hline \multicolumn{3}{|l|}{ Status gizi } \\
\hline Gizi lebih dan baik, n (\%) & $24(40)$ & $20(33,3)$ \\
\hline Gizi kurang, n (\%) & $5(8,4)$ & $11(18,3)$ \\
\hline \multicolumn{3}{|l|}{ Asupan nutrisi } \\
\hline Bubur & 5 & 1 \\
\hline Bubur + nasi kukus & 3 & 3 \\
\hline Nasi kukus & 9 & 13 \\
\hline Makanan biasa & 12 & 14 \\
\hline Pengobatan simtomatis sebelum masuk rumah sakit, no, n (\%) & $29(48,3)$ & $31(51,7)$ \\
\hline Pemberian zinc, ya, n (\%) & $29(48,3)$ & $31(51,7)$ \\
\hline
\end{tabular}

$\mathrm{SB}=$ Simpang baku

Tabel 2. Perbandingan lama diare, peningkatan berat badan, frekuensi defekasi serta waktu untuk mencapai konsistensi feses normal dengan independent t-test

\begin{tabular}{|c|c|c|c|c|}
\hline Parameter & $\begin{array}{l}\text { Formula bebas } \\
\text { laktosa }(\mathrm{n}=29)\end{array}$ & $\begin{array}{l}\text { Formula mengandung } \\
\text { laktosa }(\mathrm{n}=31)\end{array}$ & $\mathrm{p}$ & $\begin{array}{l}\text { Beda rerata } \\
(\text { IK } 95 \%)\end{array}$ \\
\hline Durasi diare di rumah sakit (jam), rerata $(\mathrm{SB})$ & $57,59(9,40)$ & $85,97(13,94)$ & 0,001 & $\begin{array}{c}28.38 \\
(22,19 ; 34,56)\end{array}$ \\
\hline $\begin{array}{l}\text { Waktu mencapai konsistensi feses normal (jam), } \\
\text { rerata (SB) }\end{array}$ & $41,06(11,16)$ & $71,00(14,84)$ & 0,001 & $\begin{array}{c}29.93 \\
(23,10 ; 36,76)\end{array}$ \\
\hline Penambahan berat badan $(\mathrm{kg})$, rerata $(\mathrm{SB})$ & $0,10(0,15)$ & $0,13(0,14)$ & 0,384 & $\begin{array}{c}0,03 \\
(-0,04 ; 0,10)\end{array}$ \\
\hline Frekuensi defekasi, (kali) rerata (SB) & $15,59(3,68)$ & $25,23(4,71)$ & 0,001 & $\begin{array}{c}9,64 \\
(7,44 ; 11,84)\end{array}$ \\
\hline
\end{tabular}


Dua puluh sembilan subyek masuk ke kelompok A (formula bebas laktosa) dan 31 subyek masuk kelompok B (formula standar). Umur subyek berada pada rentang 6-48 bulan. Tidak terdapat perbedaan bermakna karakteristik dasar subyek penelitian pada kedua kelompok. Karakteristik dasar subyek penelitian tertera pada Tabel 1.

Rerata lama diare pada kelompok formula bebas laktosa 57,59 jam (SB 9,40) dan formula standar 85,97 jam (SB 13,94), \{beda rerata: 28,38 jam (SE 3,09) (IK95\%: 22,19; 34,56), $\mathrm{p}=0,001\}$. Rerata lama diare lebih pendek pada kelompok formula bebas laktosa dibandingkan dengan kelompok formula standar. Berat badan antara dua kelompok pada saat dipulangkan dari rumah sakit tidak berbeda nyata \{beda rerata 0,03 kg (SE 0,03) (IK95\%: -0,04;0,10), $\mathrm{p}=0,384)$. Frekuensi defekasi secara bermakna lebih rendah pada kelompok formula bebas laktosa dibandingkan dengan kelompok formula standar \{beda rerata 9,64 kali (SE 1.10) (IK95\%: 7,44;11,84), $\mathrm{p}=0,001\}$. Waktu untuk mencapai konsistensi feses seperti normal secara bermakna lebih pendek pada kelompok formula bebas laktosa dibandingkan dengan kelompok formula standar \{beda rerata: 29,93 jam (SE 3,41) (IK95\%: 23,10;36,76), p=0,001\} (Tabel 2).

Berdasarkan analisis Kaplan-Meier, angka kesembuhan diare secara bermakna lebih pendek pada formula bebas laktosa dibandingkan dengan kelompok formula standar. Rerata waktu kelangsungan hidup 57,59 jam, (IK95\%: 54,16;61,01, p=0,001) pada kelompok formula bebas laktosa dan 85,97 jam (IK95\%: 81,06;90,87, p=0,001) pada kelompok formula standar.

Tabel 3. Hubungan antar variabel yang mempengaruhi penyembuhan diare akut rotavirus pada kelompok formula bebas laktosa dengan formula standar

\begin{tabular}{lccccc}
\hline Variabel & $\mathrm{B}$ & $\mathrm{SE}$ & $\mathrm{p}$ & $\mathrm{OR}$ & $\mathrm{IK} 95 \%$ \\
\hline $\begin{array}{l}\text { Intervensi } \\
\text { Status gizi }\end{array}$ & $-3,078$ & 0,53 & 0,001 & 0,046 & 0,$016 ; 0,13$ \\
$\quad$ Gizi baik dan gizi lebih & & & & \\
$\quad$ Antibiotik sebelum masuk rumah sakit & 0,146 & 0,300 & 0,626 & 1,157 & 0,$643 ; 2,084$ \\
$\quad$ Diare sebelum masuk rumah sakit & $-0,014$ & 0,014 & 0,340 & 0,987 & 0,$960 ; 1,014$ \\
$\quad$ Umur & 0,001 & 0,017 & 0,992 & 1,000 & 0,$967 ; 1,034$ \\
Asupan nutrisi & & & & & \\
$\quad$ Bubur & 0,672 & 0,633 & 0,288 & 1,959 & 0,$566 ; 6,779$ \\
$\quad$ Bubur+ nasi kukus & $-0,619$ & 0,613 & 0,312 & 0,538 & 0,$162 ; 1,790$ \\
$\quad$ Nasi kukus & $-0,054$ & 0,409 & 0,894 & 0,947 & 0,$425 ; 2,109$ \\
\hline
\end{tabular}

$\mathrm{B}=$ coeficient of Cox regression; $p=$ probabilitas, OR = Odd Ratio; IK 95\% = interval kepercayaan $95 \%$

Tabel 4. Rerata kadar serum elektrolit awal dengan independent t-test

\begin{tabular}{lcccc}
\hline Elektrolit serum & $\begin{array}{c}\text { Formula bebas laktosa } \\
(\mathrm{n}=29)\end{array}$ & $\begin{array}{c}\text { Formula mengandung laktosa } \\
(\mathrm{n}=31)\end{array}$ & $\mathrm{p}$ & Beda rerata (IK 95\%) \\
\hline Natrium & $134,3(3,8)$ & $134,6(4,3)$ & 0,785 & $0,29(-1,83-2,41)$ \\
Kalium & $3,9(0,5)$ & $3,9(0,6)$ & 0,601 & $-0,07(-0,37-0,22)$ \\
Klorida & $106,9(4,0)$ & $108,9(4,0)$ & 0,058 & $2,00(-0,07-4,09)$ \\
\hline
\end{tabular}

Tabel 5. Perbandingan rerata kadar elektrolit dengan paired t-test

\begin{tabular}{lcccc}
\hline Intervensi & Elektrolit & Rerata, (SB) & IK 95\% & $\mathrm{p}$ \\
\hline Formula mengandung laktosa & Natrium & $-0,98(4,20)$ & $-4,42-1,34$ & 0,051 \\
& Kalium & $-0,17(0.47)$ & $-0.35-0.01$ & 0,058 \\
& Klorida & $-0,15(4.49)$ & $-1,80-1,48$ & 0,846 \\
Formula bebas laktosa & Natrium & $-1,62(3,17)$ & $-2,83-0,41$ & 0,010 \\
& Kalium & $-0,09(0,45)$ & $-0,26-0,08$ & 0,279 \\
& Klorida & $0,11(4,18)$ & $-1.47-1.70$ & 0,885 \\
\hline
\end{tabular}




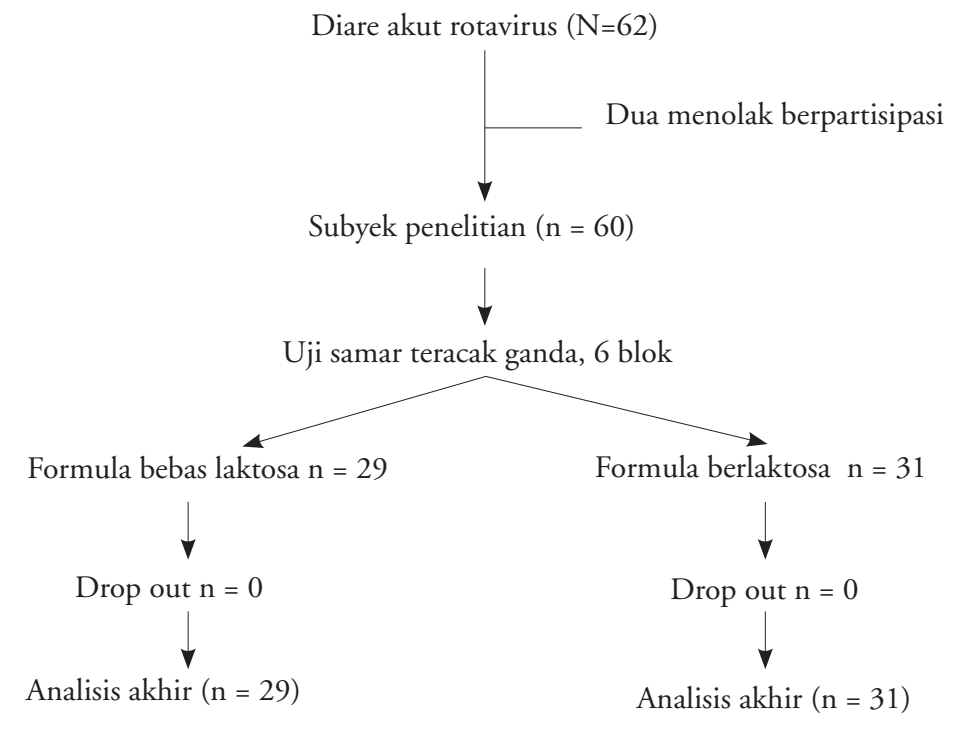

Gambar 1. Skema alur peneltian, randomisasi, follow-up dan analisis akhir

Analisis multivariat menunjukkan hanya intervensi yang diberikan yang bermakna terhadap lama diare, sedangkan faktor lain seperti umur, status gizi, asupan gizi, lama diare sebelum masuk rumah sakit dan antibiotik tidak memiliki efek yang bermakna (Tabel 3).

Rerata kadar serum elektrolit awal pada kelompok formula bebas laktosa tidak berbeda bermakna dibandingkan dengan kelompok formula standar (Tabel 4). Rerata kenaikkan kadar serum elektrolit setelah pemeriksaan elektrolit yang kedua menunjukkan bahwa peningkatan secara bermakna hanyalah pada kadar serum Natrium pada kelompok yang mendapat formula bebas laktosa (Tabel 5).

\section{Pembahasan}

Diare rotavirus secara langsung menyebabkan berkurangnya penurunan produksi enzim laktosa, sehingga menyebabkan penyerapan laktosa menurun. Laktosa yang tidak terserap meningkatkan tekanan osmotik dalam usus sehingga terjadi diare osmotik. Seiring diare sekretorik yang terjadi, diare osmotik pada infeksi rotavirus dapat menyebabkan penundaan penyembuhan, serta kehilangan cairan, dan elektrolit.

Penelitian kami membandingkan hasil antara formula bebas laktosa dan formula standar dalam pengelolaan diare rotavirus. Penggunaan formula bebas laktosa dalam tata laksana diare akut telah dilaporkan pada beberapa penelitian, dan menunjukkan penurunan yang signifikan dalam lama diare akut dibandingkan dengan formula standar. ${ }^{10}$

Sack dkk, ${ }^{13}$ menunjukkan bahwa tidak ada perbedaan yang bermakna antara lama diare akut pada penggunaan oral sukrosa atau larutan glukosa elektrolit dibandingkan dengan cairan intravena dalam tata laksana diare akut. Dehidrasi pada diare akut dapat dikelola dengan rehidrasi sukrosa oral atau glukosa, membuktikan bahwa malabsorbsi terjadi pada diare rotavirus.

Penelitian kami menunjukkan bahwa lama diare rotavirus dengan formula bebas laktosa lebih pendek dibandingkan dengan kelompok formula standar dengan perbedaan yang bermakna. Hasil serupa juga ditunjukkan oleh Simakachron $\mathrm{dkk},{ }^{10}$ memberikan formula bebas laktosa pada pasien dengan diare akut rotavirus. Dalam penelitian Lazano $\mathrm{dkk},{ }^{14}$ menunjukkan tidak ada perbedaan yang bermakna dalam lama diare akut pada kelompok bebas laktosa dibandingkan dengan kelompok formula standar. Perbedaan hasil tersebut kemungkinan disebabkan karena sampel yang sedikit serta tidak menyebutkan etiologi diarenya.

Dalam penelitian kami, kelompok formula bebas laktosa memiliki frekuensi diare yang lebih jarang secara bermakna dibandingkan dengan kelompok susu 
formula standar. Hasil serupa juga dilaporkan dalam penelitian yang dilakukan oleh Santosham dkk., ${ }^{15}$ yang menggunakan formula bebas laktosa setelah diare akut terehidrasi, menunjukkan penurunan frekuensi diare. Simakachorn dkk., ${ }^{10}$ juga mendapatkan hasil yang sama yaitu penurunan frekuensi diare pada kelompok formula bebas laktosa.

Berat badan akhir pada penelitian kami tidak berbeda bermakna secara statistik antara kelompok formula bebas laktosa dan kelompok formula staandar. Simakachorn $\mathrm{dkk},{ }^{10}$ menunjukkan peningkatan yang tidak berbeda bermakna secara statistik berat badan setelah dua hari pengamatan.

Temuan kami menunjukkan bahwa walaupun pada awal penelitian kadar serum Natrium hanya sedikit di bawah normal, tetapi tata laksana nutrisi dengan formula bebas laktosa secara bermakna mampu meningkatkan kadar serum Natrium dibandingkan formula standar. Formula bebas laktosa mudah diserap walaupu enzim laktase kurang pada diare rotavirus. Keadaan tersebut menyebabkan tekanan osmtik intraluminal rendah, sehingga kehilangan air dan elektrolit berkurang. ${ }^{16}$ Disimpulkan bahwa formula bebas laktosa dapat mempersingkat lama diare dan meningkatkan serum natrium pada diare rotavirus.

\section{Daftar pustaka}

1. Boschi-Pinto C, Velebit L, Shibuya K. Estimating child mortality due to diarrhoea in developing countries. Bull World Health Organ 2008; 86: 710-7.

2. Departemen Kesehatan Republik Indonesia. Profil kesehatan Indonesia 2001. Depkes RI; September 2004.

3. Bernstein DI, Ward RL. Rotavirus infection. Pediatrics in Review 2003; 24:322-3.

4. Bresee J, Fang ZY, Wang B, Nelson EAS, Tam J, Soenarto $\mathrm{Y}$, dkk. First report from the Asian rotavirus surveillance network. Emerg Infect Dis 2004; 10:988-95.

5. CDC. Sixth international rotavirus symposium: Global burden of rotavirus disease. Mexico city: CDC; Juli
2004.

6. CHOICE Study group. Multicenter, randomized, double-blind clinical trial to evaluate the efficacy and safety of a reduced osmolarity oral rehydration salts solution in children with acute watery diarrhea. Pediatrics 2001; 107:613-8

7. Soenarto SY, Aman TA, Bakri A, Waluya H, Firmansyah A, Kadin M, dkk. The burden of severe rotavirus diarrhea in Indonesia. J Infectious Diseases. In Press 2008.

8. Brown KH, Peerson JM, Fontaine O. Use of nonhuman milks in the diatery management of young children with acute diarhhea: a meta-analysis of clinical trial. Pediatrics 1994; 93:1-7

9. Murphy MS. Guidelines for managing acute gastroenteritis based on systematic review of published research. Arch Dis Child 1998; 7:279-84.

10. Simakachorn N, Tongpenyai Y, Tangtan O, Varavithya W. Randomized double-blind clinical trial of lactosa-free and lactose-containing formula in dietary management of acute childhood diarrhea. J Med Assoc Thailand 2004; 87:641-9.

11. Suharyono, Boediarsi, Aswitha, Halimun EM, Penyunting. Gastroenterologi anak praktis. Jakarta: Balai Penerbit FKUI; 1988.

12. Lemeshow S, Hosmer DW, Klar J, Lwanga SK. Adequacy of sample size in health studies. New York: Wiley; 1990.

13. Sack DA, Chowdhury AM, Eusof A, Ali MA, Merson $\mathrm{MH}$, Islam $\mathrm{S}$, dkk. Oral hydration rotavirus diarrhoea: a double blind comparison of sucrose with glucose electrolyte solution. Lancet 1978; 2:280-3.

14. Lozano JM, Cespedes JA. Lactose vs. lactose free regimen in children with acute diarrhoea: a randomized controlled trial. Arch Latinoam Nutr 1994; 44:6-11.

15. Santosham M, Foster S, Reid R, Bertrando R, Yolken R, Burns B, dkk. Role of soy-based, lactose-free formula during treatment of acute diarrhea. Pediatrics 1985; 76:292-8.

16. Parashar UD, Hummelman EG, Breese JS, Miller MA, Glass RI. Global illness and Death Caused by Rotavirus Disease in Children. Emerg Infect Dis 2006; 9:56572. 